\title{
THE ROLE OF ARBITRATION IN THE RESOLUTION OF INTERNATIONAL COMMERCIAL DISPUTES*
}

\author{
Mohammad Naqib Ishan Jan** \\ Abdulrashid Lawan Haruna***
}

\begin{abstract}
There are several methods of dispute resolution which are available to parties in international commercial contracts. However, arbitration has been enjoying overwhelming patronage and dominance over allother dispute resolution methods that are at the disposal of disputants. The article examines the role of arbitration in the resolution of international commercial disputes with a view to portraying its significance in the resolution of commercial disputes that have certain foreign elements. In doing so, the article considers the arbitration agreement, how it features in commercial contracts and the necessary elements for its recognition and enforceability. The article
\end{abstract}

The earlier version of this article was presented at International Conference on Commercial Law (ICCL2013), International Islamic University Malaysia 2013, organised by Ahmad Ibrahim Kulliyyah of Laws.

** $\quad$ Professor of Law, Ahmad Ibrahim Kulliyyah of Laws, International Islamic University Malaysia and the Coordinator of ADR Research Cluster, AIKOL, IIUM

*** Ph.D. Candidate, Ahmad Ibrahim Kulliyyah of Laws, International Islamic University Malaysia, and Lecturer, Faculty of Law, University of Maiduguri, Nigeria 
further examines the factors responsible for the significant role of arbitration and its prevalence in the resolution of international commercial disputes. In view of such task and in order to critically bring out the attractive role of arbitration, the article discusses advantageous features of arbitration such as the parties'freedom, neutrality of the arbitrators, the applicable law and the seat of arbitration, flexibility of the process, confidentiality and transnational enforcement of awards. In view of these merits, it is recommended that parties to international commercial transactions should have an arbitration agreement in their contracts in order to allow reference to arbitration in resolving their future commercial disputes.

Keywords: arbitration agreement, party autonomy, arbitrability, dispute resolution

\title{
PERANAN TIMBANGTARA DI DALAM PENYELESAIAN PERTIKAIAN KOMERSIL ANTARABANGSA: SUATU PENILAIAN KRITIS
}

\begin{abstract}
ABSTRAK
Terdapat beberapa kaedah penyelesaian pertikaian yang disediakan untuk pihak-pihak dalam kontrakkontrak komersil antarabangsa. Walaubagaimanapun, timbangtara telah mendapat sambutan yang hebat dari kalangan pihak-pihak yang bertikai dan ia mendominasi semua kaedah lain dalam penyelesaian pertikaian. Artikel ini mengkaji peranan timbangtara dalam penyelesaian pertikaian-pertikaian komersil antarabangsa dengan tujuan untuk melihat kepentingannya dalam penyelesaian pertikaianpertikaian komersil yang wujud di dalamnya unsurunsur asing yang tertentu. Dalam berbuat demikian,
\end{abstract}


artikel ini memberi pertimbangan kepada perjanjian yang mengandungi peruntukan timbangtara, bagaimana ia diperuntukkan dalam kontrak-kontrak komersil dan juga unsur-unsur yang perlu bagi pengiktirafan dan penguatkuasaannya. Artikel ini selanjutnya mengkaji faktor-faktor yang menjadikan peranan timbangtara itu begitu signifikan dan keutamaannya dalam penyelesaian pertikaian komersil antarabangsa. Selari dengan tugasan tersebut dan juga bagi melihat secara kritis peranan menarik yang dimainkan oleh timbangtara, artikel ini membincangkan ciri-ciri kelebihan timbangtara antaranya kebebasan pihak-pihak, penimbangtarapenimbangtara yang berkecuali, undang-undang yang boleh diterima pakai dan Pusat Timbangtara, proses timbangtara yang fleksibel, kerahsiaan dan juga penguatkuasaan transnasional keatas awad yang diberikan. Berdasarkan merit ini, adalah disarankan bahawa pihak-pihak kepada transaksi komersil antarabangsa seharusnya memasukkan peruntukan timbangtara dalam kontrak-kontrak mereka bagi membolehkan rujukan dibuat kepada Penimbangtara dalam menyelesaikan pertikaian komersil mereka pada masa hadapan.

Kata Kunci: perjanjian timbangtara, autonomi kepada pihak-pihak, boleh ditimbangtara, penyelesaian pertikaian

\section{INTRODUCTION}

Generally, disputes in international commercial contracts is an inevitable phenomenon that features all the time in the dealings of the contracting parties. Arbitration in international commercial disputes is less concerned with the causes of the dispute but rather, how to resolve the existing or future dispute that may arise from the parties' contract. There are several methods of dispute resolution, which include court litigation, reconciliation, mediation, negotiation and arbitration. However, among these methods, arbitration has become the prominent and most preferred method of dispute resolution, 
particularly in disputes involving commercial transactions that has foreign elements. Certain factors account for the growing trend of arbitration in international commercial disputes. Some of these factors are the freedom of parties in deciding issues such as the seat of arbitration, the applicable law, the arbitrators, the flexibility involved in the process of the arbitration; the neutrality that flows from the exercise of parties' freedom; confidentiality of the process; and above all, the transnational enforcement of the arbitration award. These factors are responsible for the significant and dominant role of arbitration in international commercial arbitration. However, this is not to say that international commercial arbitration has no problems since there are certain factors that sometimes impede the effectiveness of the arbitration.

It is against this background that this article intends to briefly consider the meaning and the nature of arbitration in international commercial disputes with a view to contextualising the concept for the discussions that will follow. The article discusses the arbitration clause and submission agreement as the means through which an arbitration agreement features in commercial contracts. It equally discusses the essential elements of a valid an arbitration agreement being the prerequisite for the effectiveness of arbitration agreement. The article further discusses the attractive characteristics of arbitration, which have been instrumental for the efficient and positive role of arbitration in international commercial disputes.

\section{MEANING AND NATURE OF AN ARBITRATION AGREEMENT}

Arbitration is an independent dispute resolution method among the various methods of dispute resolutions and mechanisms. It 'is one of the dispute resolution methods which [is] conducted by a neutral third party in accordance with the arbitration agreement ${ }^{1}$ Arbitration is the process of resolving business disputes between or among transnational parties through the use of one or more arbitrators

$1 \quad$ Belma Bulut, "The Role of the Place of Arbitration in International Commercial Arbitration Proceeding; Turkey as a Place of Arbitration", Ankara Bar Review Vol. 1 (2011):, 35 
rather than through courts. ${ }^{2}$ Arbitration is an alternative to the public court system as well as litigation as methods of dispute resolution. International commercial arbitration is an arbitration that is of commercial nature and it has certain foreign elements. ${ }^{3}$ International commercial arbitration has now become one of the popular methods of resolving commercial disputes involving transactions with international elements. The popularity was driven from its flexible nature and party's freedom. ${ }^{4}$

In line with the growing trend of international commercial arbitration in international trade disputes, the United States Supreme Court has for long admitted the dominance of arbitration in international commercial dispute resolution. According to the Court, the way 'international trade has expanded in recent decades, so too has the use of international arbitration to resolve disputes arising in the course of that trade'. ${ }^{5}$ It is important to mention that despite the confidentiality

2 Allen B. Green and Willian O' Brein, International Arbitration and Multi-National Litigation of Commercial Dispute at 2 available at www.mckannalong.com (accessed 25 January 2014)

3 United Nations, "International Commercial Arbitration", United Nations Conference on Trade and Development, New York and Geneva, (2005), at 3. According to Article 1 (3) of the UNCITRAL Model law, an arbitration is international if:

(a) the parties to an arbitration agreement have, at the time of the conclusion of that agreement, their places of business in different States; or

(b) one of the following places is situated outside the State in which the parties have their places of business:

(i) the place of arbitration if determined in, or pursuant to, the arbitration agreement;

(ii) any place where a substantial part of the obligations of the commercial relationship is to be performed or the place with which the subject-matter of the dispute is most closely connected; or

(c) the parties have expressly agreed that the subject matter of the arbitration agreement relates to more than one country. Ar. Gör. Şeyda Dursun, "A Critical Examination of the Role of Party Autonomy in International Commercial Arbitration and an Assessment of its Role and Extent' Vol. 1 (2012) Yalova Üniversitesi Hukuk Fakültesi Dergisi, at 161

$5 \quad$ Mitsubishi Motors Corp. v. Soler Chrysler-Plymouth, Inc., 473 U.S. 614, 638 (1985) 
involved in commercial arbitration, ninety percent of international trade agreements or contracts contain an arbitration clause that spells out the mode of dispute resolution. ${ }^{6}$ This further buttresses the significant role of international commercial arbitration in the satisfactory resolution of commercial disputes that have foreign or international elements. A more detailed advantage of arbitration in international commercial dispute will be discussed below after establishing a background on the workings of arbitration.

As stated earlier, an arbitration agreement is made by parties with a view to submitting future or existing disputes to arbitration. The arbitration agreement must be put into writing, explicitly obliging the parties to use arbitration in cases of dispute. ${ }^{7}$ It is such agreement of the parties that makes the future award binding for the parties. ${ }^{8}$ Gilles observes that in considering the traditional method of voluntary arbitration, "the legitimacy of arbitrators flows from the agreement of the parties. By agreeing to have their dispute settled by way of arbitration, the parties have not only empowered the arbitrators, but also abided by the power that they have conferred on them'.?

In other words, the essence of having an arbitration agreement is for the purpose of empowering independent arbitrator(s) to determine issues and disputes that may arise in the course of commercial dealings. ${ }^{10}$ Additionally, the mere fact that the parties have agreed to arbitrate coupled with the powers the arbitrator(s) may assume, any award made by the arbitrators has become a binding decision. ${ }^{11}$ Consequently, the

$6 \quad$ Gilles Cuniberti, "Beyond Contract-The Case for Default Arbitration in International Commercial Disputes", Fordham International Law Journal, vol. 32(2) (2008):417.

$7 \quad$ Christoph Schreuer, The Relevance of Public International Law in International Commercial Arbitration: Investment Disputes, at 4-5 available at www.univie.ac.at/intlaw/pdf/csunpublpaper_1.pdf (accessed 29 January 2014).

$8 \quad$ Andrew Barraclough and Jeff Waincymer, "Mandatory Rules of Law in International Commercial Arbitration", Melbourne Journal of International Law, vol. 6 (2005):5.

$9 \quad$ Gilles Cuniberti, "Beyond Contract-The Case for Default Arbitration in International Commercial Disputes", Fordham International Law Journal, vol. 32(2) (2008):415.

10 Andrew Barraclough and Jeff Waincymer, Mandatory Rules of Law in International Commercial Arbitration, 15.

$11 \quad$ Id, at 5 . 
award received is enforceable under the Convention on the Recognition and Enforcement of Foreign Arbitral Awards 1958 (the New York Convention). ${ }^{12}$ Besides, it is the arbitration agreement that enables parties to choose the arbitrator, language, rules, jurisdiction governing procedural issues and merits. ${ }^{13}$ Therefore, these tips have necessitated the need to make an arbitration agreement vivid and ensure that the essential elements of a valid arbitral agreement are satisfied. ${ }^{14}$

\section{ARBITRATION CLAUSES AND SUBMISSION AGREEMENTS}

In recent times, arbitration has gained ground in virtually all commercial contracts or agreements, particularly in contracts that have foreign elements or international colouration. The point that calls for question is how does arbitration gain prominence in such international agreements and contracts? The reasons for its dominance in commercial disputes are not unconnected with how it has been used and the outcome of its usage in resolving disputes. These have been responsible for its growing trend in international commercial transactions. In order to have an arbitration agreement featured in a contract, there are two ways of doing it i.e. by an arbitration clause or submission agreement.

An arbitration clause is a clause that is inserted in the main contractual agreement between the parties in a commercial

12 Convention on the Recognition and Enforcement of Foreign Arbitral Awards, 10 June 1958, entered into force, 7 June 1959 United Nations, Treaty Series, vol. 330, p. 38, No. 4739 (1959) (hereinafter 'New York Convention')

13 Claude R. Thomson and Annie M. K. Finn, "International Commercial Arbitration: A Canadian Perspective", Arbitration International, Vol. 18 No. 2, (2002): 208. Commercial arbitration is of private nature, as the arbitral process starting from setting up the tribunal to the arbitrators' powers and the binding effect of the award is virtually a product of the parties' agreement. Andrew Barraclough and Jeff Waincymer, Mandatory Rules of Law in International Commercial Arbitration, at 5

14 R. Doak Bishop, A Practical Guide for Drafting International Arbitration Clauses at 1-2 available at www.kslaw.com/library/pdf/ bishop9.pdf(accessed 2 February 2014) 
transaction. ${ }^{15}$ The clause being part of the main document, is usually short and drafted in such a way that it sets out an agreement to submit future disputes that may arise between the parties to arbitration. ${ }^{16}$ The arbitration clause is quite independent from the main contractual agreement, and it sets out some terms distinct from the terms of the main contract between the parties. ${ }^{17}$ An arbitration clause is treated and considered as such based on the doctrine of separability. Thus, since the arbitration clause is independent, it is generally drafted towards the end of the contract document and has to be carefully drafted to maximise chances of enforcement in the particular circumstances. ${ }^{18}$ The clause has to determine the scope of the authority of the Tribunal, the issues subject to arbitration, identify a place that will serve as seat for the arbitration, and set minimum rules of procedure. ${ }^{19}$

In identifying the seat for arbitration, the parties should consider a neutral situs in order to avoid favouring either of the parties. ${ }^{20}$ Parties are encouraged to choose a country that is a signatory to the New York Convention for the purpose of ease of enforcement of award, as the Convention requires due process and it gives opportunity to be heard and award be enforced..$^{21}$ Likewise, in

$15 \quad$ See Article 7 (2), UNCITRAL Model law. The UNCITRAL Model Lave was adopted by the United Nations Commission on International Trade Law (UNCITRAL) on 21 June 3985 via General Assembly Resolution A/40/17, 40 G.A.O.R. Supp. No. 53 (hereinafter 'UNCITRAL Model law'). A/40/.53

16 Christoph Schreuer, The Relevance of Public International Law in International Commercial Arbitration: Investment Disputes, 2.

17 R. Doak Bishop, A Practical Guide for Drafting International Arbitration Clauses, 6 .

18 Id, at $1-2$

19 See Gabrielle Kaufmann-Kohler, Online Dispute Resolution and its Significance for International Commercial Arbitration, in ICC, Global Reflections on International Law, Commerce and Dispute Resolution, (ICC Publishing, 2005), at 442-447. Allen B. Green and Willian O'Brein, International Arbitration and Multi-National Litigation of Commercial Dispute, 1.

Gloria Maccioli, International Commercial Arbitration, at 7, available at http://www.asil.org/jpbio.cfm (accessed 28 January 2014). The 1958 Convention on the Recognition and Enforcement of Foreign Arbitral Awards ('the New York Convention'). 
choosing the applicable law in the arbitration, the parties should consider a neutral law and perhaps the law of the seat of arbitration. This will be easier for the parties and avoids confusion in terms of conflict of laws between the law of the seat of arbitration and the chosen applicable law. ${ }^{22}$ Choice of law is significant as a tribunal is obliged to apply the law chosen by the parties. According to the Rules of International Chamber of Commerce (ICC), "the parties shall be free to agree upon the rules of law to be applied by the Arbitral Tribunal to the merits of the dispute". ${ }^{23}$

Besides the arbitration clause, there is a submission agreement. A submission agreement, unlike an arbitration clause, is made separately from the main contractual agreement as a different document. ${ }^{24}$ As such, being a separate agreement, it is usually long as opposed to an arbitration clause that is made short. A submission agreement is an agreement that is made pursuant to a subsisting contractual agreement setting out the accord of the parties to submit an existing dispute to arbitration. ${ }^{25}$ Just like an arbitration clause, a submission agreement should contain all the issues aforementioned to be covered by an arbitration clause. ${ }^{26}$ Generally, in drafting an arbitration clause or a submission agreement, the draftsman must be cautious and meticulous, as a poorly drafted arbitration clause or submission agreement may lead to non-enforcement of the arbitration award or the arbitral tribunal may decide that it lacks jurisdiction. ${ }^{27}$

$22 \quad$ Allen B. Green and O'Brein, International Arbitration and MultiNational Litigation of Commercial Dispute, at 1.

$23 \quad$ ICC Rules of Arbitration, Article 17.1; Article 7 (1), UNCITRAL Model law.

24 George A. Bermann, "Restating the U.S. Law of international Commercial Arbitration", International Law and Politics, vol. 42 (2009):176.

25 See International Commercial Arbitration, Report of the Working Group on International Contract Practices on the Work of its Fourth Session (Vienna, 4-15 October 1982) (A/CN.9/232), at 37-38

26 Peter van den Dungen and Sophie Rayner, International Arbitration Clauses in Commercial Contracts, (June 2012), 2, available at jws.com.au (accessed on 29 January 2014); Peter van den Dungen and Sophie Rayner, International Arbitration Clauses in Commercial Contracts, 1-3.

27 See Ar. Gör. Şeyda Dursun, A Critical Examination of the Role of Party Autonomy in International Commercial Arbitration and an Assessment of its Role and Extent,164-165. 
Thus, there is need for an arbitration agreement to comply with the basic elements that are necessary for the validity and enforceability of arbitration.

\section{ELEMENTS OF ARBITRATION AN AGREEMENT}

An arbitration agreement is like any other binding contract or agreement which has to satisfy certain basic requirements of the law before it can be given the force of law. For an arbitration agreement to be valid, it has to be in writing, the parties must have the legal capacity to arbitrate and they must give their consent and the subject of the agreement must be capable of arbitration.

\section{(1) Arbitration Agreement must be in Writing}

An agreement for arbitration must be in writing for otherwise it will not be given recognition. ${ }^{28}$ According to New York Convention, 'the term 'agreement in writing' shall include an arbitral clause in a contract or an arbitration agreement, signed by the parties or contained in an exchange of letters or telegrams'. ${ }^{29}$ This could mean that a mere verbal agreement between parties to a commercial contract to submit their dispute to arbitration will not suffice. There is no specific format for writing an arbitration agreement but as explained above, it can be in form of a clause in the main contractual agreement of the parties or it can be a separate document (submission agreement).$^{30}$ It is significant to address all the necessary and relevant issues that may arise in the process of arbitration. The requirement of writing is to ensure that parties have really agreed to arbitrate in view of the legal consequences attached to a concluded arbitration agreement. ${ }^{31}$ It can be recalled that agreement to arbitrate may lead

\footnotetext{
$28 \quad$ See Article 7 (2), UNCITRAL Model law; Article II, New York Convention

29 Article II (2), New York Convention

$30 \quad$ Article 7 (1), UNCITRAL Model law

31 Paul M. Hebert Law Center, Arbitration Agreements- Validity and Interpretation, available at www.faculty.law.lsu.edu/... /Chapter\%207.pdf (accessed 28 January 2014).
} 
parties to renounce their constitutional right to have their dispute heard in court. 32

In addition to putting down the agreement into writing, it has to be signed, as appending signature is a requirement of the New York convention..$^{33}$ The Convention can only give recognition and enforcement to an arbitration agreement if it is in writing and signed by the parties. However, applying strict conditions for the recognition and giving effect to an arbitration agreement has been a subject of criticism by experts in commercial arbitration. They argue that the strict requirement for an arbitration agreement does not reflect actual business practice where in some cases parties rely on oral agreements. ${ }^{34}$ Thus, modern trends in international commercial arbitration have shown that the signature is not necessary, provided that the arbitration agreement is in writing as decided in the case of Compagnie de Navigation et Transports SA (France) v. Mediterranean Shipping Co. SA (Switzerland). ${ }^{35}$ Likewise, the Court of Appeal for the Fifth Circuit in the case of Sphere Drake Insurance v. Marine Towing, ${ }^{36}$ held that signature or exchange of documents are not necessary where the arbitration clause is part of a contract. Thus, the application of strict requirement for the recognition and giving effect to an arbitration agreement is becoming swift. ${ }^{37}$ Indeed, the requirement of writing has been a subject of contention in view of recent developments in technology and telecommunications.

To be specific, the written requirement for an arbitration agreement as contained in the New York Convention raises questions in view of technological developments where parties concluded their transactions via email. In line with this problem, the United Nations Commission on International Trade Law (UNCITRAL) Model law provides for the acceptance of data

\begin{tabular}{ll}
\hline 32 & Ibid \\
33 & Article II (2), New York Convention \\
34 & Ibid \\
35 & Compagnie de Navigation et Transports SA (France) v. Mediterranean \\
& Shipping Co. SA (Switzerland), Swiss Supreme Court, 1995. \\
36 & Sphere Drake Insurance v. Marine Towing, Inc, 16 F 3d 666, 669 (5th \\
& Cir 1994). \\
& Paul M. Hebert Law Center, Arbitration Agreements- Validity and \\
& Interpretation, at 138-14.
\end{tabular}


message in place of formal writing of information. The Model law further widens the meaning of the term 'written agreement' by stating that:

An arbitration agreement is in writing if its content is recorded in any form, whether or not the arbitration agreement or contract has been concluded orally, by conduct, or by other means. The requirement that an arbitration agreement be in writing is met by an electronic communication if the information contained therein is accessible so as to be useable for subsequent reference an arbitration agreement is in writing if it is contained in an exchange of statements of claim and defence in which the existence of an agreement is alleged by one party and not denied by the other. ${ }^{38}$

This provision has given leeway for the recognition of an arbitration agreement that is contained in an e-mail or similar mediums of communication. The position has been followed in many jurisdictions that are advanced in e-commerce. ${ }^{39}$ In the case of Lieschke v. Realnetworks, Inc, a United States court upheld an arbitration agreement that was part of an online transaction. ${ }^{40}$ Therefore, where parties to an international commercial arbitration agreement concluded a commercial transaction via e-mails, such electronic data message is sufficient to satisfy the requirement of a written arbitration agreement.

\footnotetext{
$38 \quad$ Article 7 (3)(4)(5), UNCITRAL Model law

39 See Article 1(2)(a) of the European Convention on International Commercial Arbitration, 1961

40 Lieschke v. Realnetworks, Inc, no 99C 7274, 99C, 7380, 2000. Cf.Charterer (Norway) v. Shipowners (Russia Federation), XXVII YBCA 519 (2002) where a Norwegian Court of Appeal refused to enforce an arbitration agreement that was contained in e-mail.
} 


\section{(2) Capacity of the Parties}

An arbitration agreement, like any other contract can be made by any legal entity, which may be either a natural persons or body corporate (legal person). The capacity of the parties is essential in view of the legal consequence that ensues upon conclusion of an arbitration agreement. ${ }^{41}$ Ordinarily, the law to be used to determine the capacity of the parties is the law of their domicile, but in the case of international commercial arbitration, it is the law chosen by the parties that will be used or the law of the seat of arbitration as the case may be..$^{42}$ Where both or either party to the arbitration is a body corporate, the law of the place of incorporation of the body will be used to determine its capacity or in the case of international commercial arbitration, the law applicable to the arbitration will be used. ${ }^{43}$

In agreements concerning corporate person, it is important to note that, a body corporation acts through its directors or officials who must act within their powers (intra vires), which means they should not act ultra vires. ${ }^{44}$ It is trite law that where directors of a body corporate act ultra vires, their capacity in this respect would be lacking. Similarly, a state and state agency can equally act as persons by entering into a contract on behalf of the stateor state agency, which must also have the necessary authority to do so. ${ }^{45}$ Generally,

$41 \quad$ See the consequence of lack of capacity in the provisions of Articles 34(2)(a)(i) and 36 (1)(a)(i), UNCITRAL: Model law

42 Paul M. Hebert Law Center, Arbitration Agreement- Validity and Interpretation, at 140 .

43 Robert French, International Commercial Dispute Resolution and the Place of Judicial Power (22 August 2013) a Paper delivered at International Commercial Law and Arbitration Conference, Sydney, 13-14; Giuditta Cordero Moss, "Legal Capacity, Arbitration and Private International Law" in Convergence and Divergence in Private International Law, edited by K. Boele-Woelki, et al, (Utrecht: Liber Amicorum Kurt Siehr, 2010): 12; Thomas J. Brewer and Lawrence R. Mills, "When Arbitrators Exceed their Powers: A New Study of Vacated Arbitration Awards February", Dispute resolution Journal,(April 2009): 49.

44 Giuditta Cordero Moss, Legal Capacity, Arbitration and Private International Law, at 12-14

45 Bryant Smith, Legal Personality, vol. 12, No. 1 (2011) Suspicious News Magazine, 80; Valts Nerets, "Nationality of Investors in ICSID 
where a party to an arbitration agreement either, natural or body corporate, lacks capacity, such defect invalidates the arbitration agreement.

\section{(3) Consent of Parties}

The foundation stone of arbitration is the consent of the parties expressed in writing. An arbitration agreement needs the consensus of the parties to agree to send their dispute to arbitration. ${ }^{46} \mathrm{~A}$ binding contract requires consensus ad idem (meeting of the minds) of the parties, which is also referred to as mutual agreement or mutual assent. ${ }^{47}$ It is expected that the various issues relevant to arbitration must be consented to by the parties. Parties must consent to appointment of arbitrators, the seat and the venue of the arbitration proceedings, choice of language and other procedures for proceedings and pleadings. ${ }^{48}$ In the absence of consent, there can be no arbitration, since the authority of the Tribunal is derived from the conferral power of the parties.

As earlier point out by Gilles, 'the legitimacy of arbitrators flows from the agreement of the parties. By agreeing to have their dispute settled by way of arbitration, the parties have not only empowered the arbitrators, but also abided by the power that they have conferred on them' ${ }^{49}$ Recent practice shows that the Model law requirement of written consent is no longer the practice in some jurisdictions, as a written arbitration agreement without any objection to the contrary suffices. ${ }^{50}$ In a more apt language, consent can be inferred from the dealings of the parties when they make reference to a document containing an arbitration clause even without making a

Arbitration", Riga Graduate School of Law Reseach Paper, No. 2, (2011): 18 -22.

Rowland James Victor Cole, Some Reflections on International Commercial Arbitration, (Master Thesis: University of South Africa, 2003), at 7.

$47 \quad$ Ibid

$48 \quad$ Ibid

49 Gilles Cuniberti, "Beyond Contract-The Case for Default Arbitration in International Commercial Disputes", Fordham International Law Journal, vol. 32(2) (2008): 415.

$50 \quad$ See section 1031 (2), German Law. 
specific reference to the clause. This assertion is supported by the provision of the UNCITRAL Model law, which provides that 'the reference in a contract to a document containing an arbitration clause constitutes an arbitration agreement provided that the contract is in writing and the reference is such as to make that clause part of the contract'. ${ }^{51}$ The Swiss Tribunal Federal has taken a similar decision in the case of Tradax Export v. Amoco Iran Oil Company. ${ }^{52}$ Though, the Tribunal used Article II (2) of the New York convention, it held that generic reference without specific mention of the arbitration clause suffices.

\section{(4) Arbitrability}

Arbitrability is a recurring phenomenon in commercial arbitration as it affects the core of the arbitration agreement. It deals with ascertaining whether arbitrators have jurisdiction to arbitrate over the matter in dispute and it involves determining which types of dispute may be resolved by arbitration and which belong exclusively to the domain of the courts. ${ }^{53}$ According to the UNCITRAL Model law, an arbitral tribunal may decide on whether it can assume jurisdiction over a dispute submitted to it or not. The law provides to the effect that 'the arbitral tribunal may rule on its own jurisdiction, including any objections with respect to the existence or validity of the arbitration agreement'. ${ }^{54}$ This provision has established the principle called 'competence-competence', which is simply referring to jurisdiction concerning jurisdiction. ${ }^{55}$ Generally, where parties did not confer the power to determine arbitrality on the arbitrators, the court

\footnotetext{
$51 \quad$ Article 7 (2), UNCITRAL Model Law.

52 Tradax Export SA (Panama) v. Amoco Iran Oil Company, Tribunal Federal (US), XI YBCA (1986).

53 See Article II (1) and V (2) and Article 36 (1)(b)(i), UNCITRAL Model law. UNCITRAL Model law provides that recognition or enforcement cannot be secured when the subject-matter of the dispute is not capable of settlement by arbitration under the law of the State.

$54 \quad$ Article 16 (1), UNCITRAL Model law

55 George A. Bermann, "The "Gateway" Problem in International Commercial Arbitration", The Yale Journal of International Law, vol. 37 (2012): 14.
} 
will determine the arbitrality of the dispute submitted. It was held by the United States Supreme Court in the case of First Options of Chicago, Inc. v. Kaplan ${ }^{56}$ that in determining whether a dispute is arbitrable, it is the court that will decide except if the parties have agreed that the arbitrators should determine the arbitrality of the dispute.

It is important for the parties empowering arbitrators to determine arbitrality to categorically state the extent of the arbitrators' authority. For instance, they may state that: 'the arbitrators may look at their jurisdiction without waiting for a court to do so, ${ }^{57}$ 'the arbitrators may decide their own jurisdiction in the first instance without court intervention until after an award is rendered, at which time a court may review jurisdiction' or; ${ }^{58}$ 'the arbitrators may decide their own jurisdiction in a binding manner with no court review. ${ }^{59}$ Making such clarification will further curb chances of unnecessary challenges. Note that, generally, there are certain issues that by the operation of law are conclusively recognised as subjects outside the realm of arbitration. ${ }^{60}$ These issues include criminal matters including bribery and corruption, as well as bankruptcy or insolvency. Meanwhile, the courts in rare occasions may declare certain categories of disputes as incapable of arbitration. ${ }^{61}$

It is important at this juncture to point out that although in the case of an arbitration clause, the clause is part of the main contractual agreement but it is treated and recognised as an independent agreement. ${ }^{62}$ Thus, the clause has to be treated as such so that if the main contract itself is illegal and void, it does not affect or render the

56 First Options of Chicago, Inc. v. Kaplan, 514 U.S. 938, 115 S.Ct. 1920, 1923-24 (1995)

57 R. Doak Bishop, A Practical Guide for Drafting International Arbitration Clauses, 55.

$58 \quad$ Ibid

$59 \quad$ Ibid

60 George A. Bermann, "Restating the U.S. Law of International Commercial Arbitration" at 176.

61 George A. Bermann, "The "Gateway" Problem in International Commercial Arbitration", at 12.

62 L. Mistelis, Applicable Laws and Procedures in International Commercial Arbitration, (London: University of London Press, 2005), 18; George A. Bermann, "The "Gateway" Problem in International Commercial Arbitration", at 22. 
arbitration clause invalid. The UNCITRAL Model Law in this context provides that:

\begin{abstract}
[A]n arbitration clause which forms part of a contract shall be treated as an agreement independent of the other terms of the contract. A decision by the arbitral tribunal that the contract is null and void shall not entail ipso jure the invalidity of the arbitration clause. ${ }^{63}$
\end{abstract}

The provision has buttressed the severability of an arbitration agreement from the main contractual pact of the parties. In line with this notion, a doctrine of separability has been enunciated and simply considers an arbitration clause in a contract as an independent contract. In essence, the "main commercial contract is the primary contract and the arbitration clause is a secondary contract'. ${ }^{64}$ In effect, where the arbitration clause is valid, only the arbitrator decides the validity of the rest of the contract. Likewise, in case where one element of the arbitration clause is invalid, that does not render the rest of the clause invalid as decided in the case Harbour Assurance v. Kansas General International Insurance Co. Ltd ${ }^{65}$ It is important to note when all the basic elements of arbitration are satisfied, arbitration can either take place in an ad hoc tribunal or arbitral institution.

\title{
$A D H O C$ AND INSTITUTIONAL ARBITRATION
}

Parties to an international commercial transaction may arbitrate their dispute in either of these two ways i.e. parties can refer their dispute to an ad hoc arbitration tribunal or to an arbitral institution for

\footnotetext{
63 Article 16 (1), UNCITRAL Model law.

64 Ar. Gör. Şeyda Dursun, A Critical Examination of the Role of Party Autonomy in International Commercial Arbitration and an Assessment of its Role and Extent, at 168.

65 Harbour Assurance v. Kansas General International Insurance Co. Ltd., (1991) QB (Commercial Court). A good example is if the arbitration clause specifies an arbitral forum or arbitration institution that does not exist will not invalid the rest of the clause.
} 
arbitration. Arbitration according the United Nations Commission for International Trade Law (UNCITRAL) means 'any arbitration whether or not administered by a permanent arbitral institution' ${ }^{66}$ In case of $a d$ hoc arbitration, UNCITRAL has a United Nations General Assembly approved arbitration rules. The rules are used in $a d$ hoc arbitration if the arbitration tribunal is to conduct the arbitration by itself or the rules can be used in arbitration to be conducted in institutional arbitration centres.$^{67}$ The UNCITRAL rules has made provisions that cover issues such as the place of arbitration, appointment and number of arbitrators, the language to be used in the arbitration and content of the parties' pleadings. ${ }^{68}$ Other issues covered are interim measures, challenges to the jurisdiction of the tribunal, evidence, costs and the effect to be given to the award of the tribunal. ${ }^{69}$ It is important to note that awards made by an ad hoc arbitration tribunal are enforceable under the New York Convention. ${ }^{70}$

In the alternative, parties to an international commercial dispute may refer their dispute to an arbitral institution for arbitration. Referring a dispute to institutional arbitration centres has its own range of advantages to both parties to a commercial dispute. Parties to a dispute may refer their dispute to any of the various institutional arbitral fora, which normally charge a fee for managing the arbitration. ${ }^{71}$ It is worthy to note that an institutional forum has its own arbitration rules, which will be used in any dispute submitted to it, except if the parties provide to the contrary. ${ }^{72}$ Interestingly, institutional arbitral centres will

\footnotetext{
$66 \quad$ Article 2 (a), UNCITRAL Model law.

67 Allen B. Green and O'Brein, International Arbitration and MultiNational Litigation of Commercial Dispute, at 6-7.

68 See Articles 10-15, UNCITRAL Model law Allen B. Green and O'Brein, International Arbitration and MultiNational Litigation of Commercial Dispute, at 7.

$70 \quad$ Ibid

71 The following are some of the major international commercial arbitration centres: International Chamber of Commerce, Court of Arbitration (ICC), founded in 1919 and based in Paris, France; London Court of International Arbitration (LCIA) based in London; American Arbitration Association (AAA), founded in 1926, and based in New York; and the World Intellectual Property Organization (WIPO), Arbitration and Mediation Center, based in Geneva, Switzerland.

$72 \quad$ See Article 19 (1), UNCITRAL Model law
} 
allow a party to a commercial dispute to proceed and obtain a default award, which can be enforced under the New York Convention. ${ }^{73}$ However, proper service of notice of hearing of the arbitration must have been made before a default award can stand the test of time. ${ }^{74}$ This position was upheld by the Circuit Court in the case of Choice Hotels International v.SM Property Management ${ }^{75}$, where the Court stated that there was no notice as required by the agreement.

Furthermore, the advantage of referring a dispute to institutional fora can equally be gleaned from the experience of the centres and services that facilitate the arbitration. Usually, an arbitral institution will provide the parties with a line-up of professional arbitrators to elect for their arbitration. ${ }^{76}$ The centres also have rules to resolve issues that may arise within an arbitral proceeding, and issues such as discovery, number and nature of pleadings, hearings and evidentiary rules, will be established by the panel. ${ }^{77}$

However, in arbitration particularly institutional arbitration, the cost of arbitration is highly expensive. The excessive cost of arbitration in this context arises from the fact that the deputing parties are to pay for the cost of proceedings, the arbitrators' fees, the arbitrators' expenses including the air fare of the arbitrator, administrative fees, fees and expenses of experts appointed by the tribunal, etc. ${ }^{78}$ According to some authors, "the cost of arbitration, particularly in international commercial disputes is high-excessively

73 Susan Wiens and Roger Haydock, "Confirming Arbitration Awards: Taking the Mystery out of a Summary Proceeding", William Mitchell Law Review, vol. 33, No.4 (2007): 1310.

74 Thomas J. Brewer and Lawrence R. Mills, "When Arbitrators Exceed their Powers: A New Study of Vacated Arbitration Awards", Dispute resolution Journal, (February -April 2009): 49-50.

$75 \quad$ Choice Hotels International v.SM Property Management, 519 F.3d 200 (4th Cir. 2008).

76 Charles N. Brower, "Keynote Address: The Ethics of Arbitration: Perspectives from a Practicing International Arbitrator", vol. 5 (Berkeley J. INT'L L. Publicist,2010): 3. Allen B. Green and O'Brein, International Arbitration and MultiNational Litigation of Commercial Dispute, at 6.

78 See George A. Bermann, "The "Gateway" Problem in International Commercial Arbitration" The Yale Journal of International Law, vol. 37, Series 1 (2012); R. Doak Bishop, A Practical Guide for Drafting International Arbitration Clauses. 
high- and often disproportionate to the amounts in dispute and, even, to the cost of similar proceedings before the court." 79 This kind of excessive cost defeats one of the major advantages of commercial arbitration over court litigation.

\section{THE APPEALING CHARACTERISTICS OF COMMERCIAL ARBITRATION}

The role of international commercial arbitration cannot be overemphasised in resolving international commercial disputes in contemporary international trade. International commercial arbitration has certain appealing features that make it desirable and preferable by most parties to commercial disputes. Its merits are numerous compare to litigation in court as a method of dispute resolution. The advantages commercial arbitration confers on disputing parties have played a significant role in making it the predominant method of resolving international commercial disputes ${ }^{80}$ Below are the benefits of submitting a dispute to arbitration.

$79 \quad$ David Hacking and Michael E. Schneider, "Towards More CostEffective Arbitration" IBA, Section on Business Law Arbitration and ADR, (1998), 26. It is important to mention that delay still occurs in practice during the arbitration process despite the fact that various Rules of arbitration discourage delay and encourage efficiency. For instance, Articles 22 and 37(5) of the International Chamber of Commerce Rules of Arbitration 2012 and Article 9(7) of the International Bar Association Rules on the Taking of Evidence in International Arbitration 1999. See David Earnest, et al., Four Ways to Sharpen the Sword of Efficiency in International Arbitration available at $\quad$ http://www.arbitrationicca.org/media/0/13630881906410 /four ways to sharpen the sword of efficiency yicca group paper.pdf(accessed on 27 September 2014)

80 Noussia K., Confidentiality in International Commercial Arbitration: A Comparative Analysis of the Position under English, US, German and French Law, at 17, available at http://www.springer.com/978-3642-10223-3 (accessed 28 January 2014). 


\section{(1) Party Autonomy}

Parties' autonomy in international commercial arbitration is a sacrosanct feature that allows the parties to a commercial transaction to choose the law that governs their arbitration in the event of dispute. This gives the parties the latitude to choose the law that is conversant to them and the one that best suits their transaction. ${ }^{81}$ It has now become trite law that parties autonomous to decide which particular rule of law to apply in arbitrating their commercial dispute. ${ }^{82}$ Both national and international legal systems have recognised the autonomous nature of parties in commercial arbitration. According to UNCITRAL Model law, ' $[\mathrm{t}]$ he arbitral tribunal shall decide the dispute in accordance with such rules of law as are chosen by the parties as applicable to the substance of the dispute' ${ }^{83}$ The provision of the UNCITRAL Model law is liberal in the sense that it allows parties to choose rules of law that has been elaborated by an arbitration institution even if the rules have not been enacted by any domestic law. ${ }^{84} \mathrm{~A}$ similar provision exists in the European Convention on International Commercial Arbitration where it states that ' $[\mathrm{t}]$ he parties shall be free to determine, by agreement, the law to be applied by the arbitrators to the substance of the dispute'. ${ }^{85}$

Arbitral institutions have equally recognised the autonomy of parties in international commercial disputes. The Rules of many arbitration institutions categorically state that parties to arbitration should be free to agree upon the rules of law to be applied by the

$81 \quad$ Helena Carlquist, Party Autonomy and the Choice of Substantive Law in International Commercial Arbitration, (Masters Thesis: Goteborg University, Spring 2006), 12.

82 Article V(1)(d), New York Convention; Article 19(1), UNCITRAL Model Law. According to the UNCITRAL Model law provision, 'the parties are free to agree on the procedure to be followed by the arbitral tribunal in conducting the proceedings'. Article 28 (1), UNCITRAL Model law. A similar provision is contained in Article 33(1), UNCITRAL Arbitration Rules, (1976)

84 Robert French, International Commercial Dispute Resolution and the Place of Judicial Power, at 3.

85 Article 7, European Convention on International Commercial Arbitration of 1961 
arbitral tribunal to the merits of their case.$^{86}$ In view of the wide spread practice of party autonomy, it has been asserted that party autonomy should be treated as a general principle of law recognised by civilized nations. ${ }^{87}$ Thus, arguably, the leeway given to parties to mutually decide the applicable law in commercial arbitration has provided for certainty and predictability of the arbitration outcome. Notwithstanding the fact that the autonomy of parties has its limitations and 'may not set the legal standards the parties thought it would' ${ }^{88}$ Importantly, the parties' right to 'choice of law' has remained the significant factor that drives parties in international commercial disputes to submit their disagreement to arbitration. ${ }^{89}$

The rationale behind such a conviction is simple, arbitration is always based on agreement between parties as an arbitration panel can only exist when there is mutual agreement for its creation. ${ }^{90}$ Essentially, the arbitration agreement becomes the backbone and primary source of authority and powers of the arbitral tribunal as well as the extent of the tribunal jurisdiction. ${ }^{91}$ Invariably, 'the parties' choice of arbitration rules cannot easily be replaced by the unilateral

$86 \quad$ See Article 17(1), International Chamber of Commerce's Arbitration Rules (ICC Arbitration Rules 2003); Article 24(1), Stockholm Chamber of Commerce's Arbitration Rules (SCC Arbitration Rules, 1999); Article 3(1), Rome Convention on the Law Applicable to Contractual Obligations of the Rome Convention, 1980

Helena Carlquist, Party Autonomy and the Choice of Substantive Law in International Commercial Arbitration, at 13. Article 38 of the Statute of the International Court of Justice of 1945 provides for sources of international law which serve as a guide to the Court and general principles of law recognised by civilized nations is one of the sources mentioned in the Article.

Helena Carlquist, Party Autonomy and the Choice of Substantive Law in International Commercial Arbitration, at 13.

Babak Hendizadeh, International Commercial Arbitration: The Effect of Culture and Religion on Enforcement of Award, (Masters thesis: Queen's University Kingston, 2012) at 12; Helena Carlquist, Party Autonomy and the Choice of Substantive Law in International Commercial Arbitration, at 1. Richard Garnett, "International Arbitration Law: Progress towards Harmonisation", Melbourne Journal of International Law, vol.3 (2002): 3 . 
decision of the arbitral institution'. ${ }^{92}$ In more succinct words, once parties have decided the manner of resolving their dispute, 'the consensual nature of arbitration demands that the manner in which they have chosen to resolve their disputes be respected in every way possible'. ${ }^{93}$ Consequently, parties to arbitration retain considerable freedom over issues such as the applicable law, the seat of arbitration, the language of the arbitration, the composition of the arbitration tribunal and the confidentiality of proceedings. ${ }^{94}$ In the end, the parties enjoy considerable flexibility and neutrality in resolving their dispute, which are also part of the merits of arbitration. ${ }^{95}$

\section{(2) Neutral Atmosphere}

International commercial arbitration provides a platform for neutrality, which flows from the freedom of parties to choose the seat of arbitration that is neutral to them. Disputants may decide to choose the seat and applicable law that belong to neither of their country in order to avoid being subjected to a law that favours either party. ${ }^{96}$ Thus, arbitration in international commercial disputes allay the fear of parties, especially 'when they come from different countries and fear being subjected to an unfamiliar and foreign judicial system' ${ }^{97}$ This feature of arbitration creates peace of mind in the disputants that arbitration will take place in a neutral seat with expertise and it greatly distinguishes arbitration from domestic court litigation where state law

92 Elizabeth Shackelford, "Party Autonomy and Regional Harmonization of Rules in International Commercial Arbitration", University of Pittsburgh Law Review, vol. 67 (2006): 900. Ibid.

Helena Carlquist, Party Autonomy and the Choice of Substantive Law in International Commercial Arbitration at 13; Richard Garnett, "International Arbitration Law: Progress Towards Harmonisation", at 3 .

95 Elizabeth Shackelford, Party Autonomy and Regional Harmonization of Rules in International Commercial Arbitration, at 903. Richard Garnett, "International Arbitration Law: Progress Towards Harmonisation", at 3. 
dictates to the parties. ${ }^{98}$

Additionally, it is difficult to litigate in a foreign court in the country of domicile of an opponent with unfamiliar law as well as novel procedure and be expected to obtain judgement and get enforcement. ${ }^{99}$ Moreover, many national courts are not free from corruption and are not independent to be able to adjudicate fairly without being biased towards foreign nationals. ${ }^{100}$ Even in cases where the national courts are independent, the judges are personnel whose backgrounds and training are based on their culture and local legislation, which may not actually favour a foreigner. ${ }^{101}$ Therefore, arbitration serves as a mechanism for bridging the gap between disputing parties who come from different backgrounds, cultures and jurisdictions, as well as it offers a satisfactory award to disputants. ${ }^{102}$ However, the issue of corruption has gradually started rearing its ugly face in international commercial arbitration. There are cases of corruption sometimes at the primary level of arbitration tribunal as well as after an award during the review by the national court. This goes to show that some obstacles that beclouded the image of

98 Babak Hendizadeh, International Commercial Arbitration: The Effect of Culture and Religion on Enforcement of Award, at 12. Where parties refer their dispute to an arbitral institution, they have the chances that the case will be dealt with by experts. According to Edna and Wilkinson 'a great benefit of arbitration is that the parties can select their arbitrators, both under the party appointed system and the list system, and thereby choose arbitrators with qualifications tailored to the needs of the arbitration in question. These desired qualifications can include attributes such as subject matter expertise; reputation for competence; temperament; number of years of experience; number of arbitrations chaired; availability; and commitment and ability to conduct an efficient, cost-effective arbitration.'

ACICA, Managing Cross-Border Disputes: International Arbitration Explained, Australian Centre for International Commercial Arbitration (ACICA), at 8 available at www.acica.org.au (accessed 26 January 2014.)

100 Gilles Cuniberti, Beyond Contract - The Case for Default Arbitration in International Commercial Disputes, 424-425.

$101 \quad$ Ibid

102 Richard Garnett, "International Arbitration Law: Progress Towards Harmonisation", at 3. 
litigation are reemerging in international arbitration and it may impact negatively on the future of international arbitration. ${ }^{103}$

\section{(3) Procedural Flexibility}

The autonomy conferred on parties in commercial arbitration has been a gateway for many attractive characteristics of international commercial arbitration. The choices parties made alter the process of arbitration in such a way that the manner and process of the arbitration is made faster, costless and more importantly, flexible in nature. ${ }^{104}$ Edna and Wilkinson aptly summarise flexibility in arbitration as follows:

The flexibility of arbitration and the opportunities it allows parties to save time and money are apparent in common arbitration practices such as: choosing a location for the hearing that will minimize costs;

103 Michael Hwang S.C. and Kevin Lim, "Corruption in ArbitrationLaw and Reality" available at http://www.arbitrationicca.org/ media/0/13261720320840/corruption in arbitration_paper draft 248.pdf (accessed on 27 September 2014); Emina Mujic, Corruption in International Commercial Arbitration: The Right of the Arbitrator to Conduct Self-Initiated Investigation of Corruption, (2013) Master's Thesis in International Process Law, International Commercial Arbitration.

ACICA, Managing Cross-Border Disputes: International Arbitration Explained, at 8-9. In terms of time consumption in arbitration compare to litigation, it was observed that 'according to statistics of the American Arbitration Association ("AAA") for the year 2008, the median length of time from the filing of an arbitration demand to the final award in domestic, commercial cases was just 7.9 months. While in 2010, the median length of time from filing through trial of civil cases in the U.S. District Court for the Southern District of New York was 33.2 months. The median length of time in 2010 from filing of a civil case in lower court to disposition of appeal by the Second Circuit Court of Appeals was 40.8 months'. See Edna Sussman and John Wilkinson, 'Benefits of Arbitration for Commercial Disputes' at 3-5 available at www.americanbar.org/.../dispute.../March (accessed 27 January 2014) 
taking witnesses out of order or interrupting a witness to accommodate individual needs; continuing a hearing after normal business hours (e.g., during the night or over a weekend) in order to complete a witness or finish the hearing; taking testimony of distant witnesses by video conference or by telephone; ordering testimony so that all experts on a topic testify directly after one another or even all at the same time (a procedure known as "hot tubbing"); and using written witness statements for some or all of the witnesses in lieu of time-consuming, oral direct testimony. ${ }^{105}$

The aforementioned factors are equally responsible for the significant role of arbitration in resolving international commercial disputes. This captivating attraction in the flexible character of arbitration provides commercial disputants with the opportunity to safe time, costs and rigidity associated with the procedure in court litigation. ${ }^{106}$

Nowadays, it is however unfortunate that there is problem of too much lawyering in contemporary international commercial arbitration. The issues such as production of documents coupled with the influx of electronic document during arbitration seem to be restricting and retarding the process of arbitration. ${ }^{107}$ This has nexus with the fact that Lawyers in international commercial arbitrations often come from various background and jurisdiction (civil law and common law) with different perceptions concerning the production of either few or large documents and it causes serious delay and cost implication to the process of arbitration. ${ }^{108}$

$105 \quad$ Edna Sussman and John Wilkinson, Benefits of Arbitration for Commercial Disputes, at 2.

106 Rowland James Victor Cole, Some Reflections on International Commercial Arbitration, at 9.

107 Nicholas Fletcher, International Arbitration Research Based Report on Perceptions of Document Production in the Arbitration Process, Berwin Leighton Paisner available at www.blplaw.com (accessed on 27 September 2014). 


\section{(4) Confidentiality}

Commercial disputes normally require certain confidentiality, particularly when the dispute involves trade secrets or intellectual property. ${ }^{109}$ Confidentiality in commercial arbitration is vitally essential, as such arbitral proceedings are held in private so that only persons designated by the parties and their counsel are allowed to attend. ${ }^{110}$ Among the choices available to parties during the drafting of an arbitration agreement includes the freedom to decide that the arbitration proceeding should be concealed with utmost confidentiality. This is a feature of arbitration that is important to international commercial transactions in which the image of a firm or company has to be protected against public damage. ${ }^{111}$ This type of leverage does not exist in court litigation where proceedings are held in public and all sundry are allowed to attend. To buttress this assertion, in the case of Hassmeh Insurance v. Mew, ${ }^{112}$ it was held that:

If the parties to an English law contract refer their dispute to arbitration they are entitled to assume at the least that the hearing will be conducted in private. That assumption arises from a practice which has been universal in London for hundreds of years and I believe undisputed. It is a practice which represents an important advantage of arbitration over the courts as a means of dispute resolution. The formality attaching to a hearing held in private and the candour to which it may give rise is an essential ingredient of arbitration.

$109 \quad$ Noussia K., Confidentiality in International Commercial Arbitration: A Comparative Analysis of the Position under English, US, German and French Law, at 16 available at http://www.springer.com/978-3642-10223-3 (accessed 28 January 2014).

$110 \quad$ Ibid

111 Gilles Cuniberti, Beyond Contract - The Case for Default Arbitration in International Commercial Disputes, at 483. Gilles further observes that 'as far as the publication of awards is concerned, recent developments in certain specialized fields of arbitration have shown that confidentiality has now become the exception rather than the norm. It is not in the very nature of arbitration to be confidential'. Hassmeh Insurance v. Mew (1993) Llyods Rep. at 246-7 
Thus, confidentiality in commercial arbitration has become the common practice and virtually all arbitral institution centres have made specific rules concerning the confidentiality of their proceedings and awards. ${ }^{113}$

However, confidentiality and party autonomy has been considered as a mechanism that can aid money laundering. It has been observed that with the increase frequency of money laundering international trade, international commercial arbitration may shield money launderers. For instance, where an international trade involved the use of money laundered by either of the parties, arbitration, unlike litigation, may not track the offender. ${ }^{114}$ In this context, one of the parties may ignore the source of the money involved in the transaction. More so, international commercial arbitration "offers at least a degree of confidentiality, the freedom to organize the proceedings, and the ability to appoint accomplices as arbitrators" thereby concealing and aiding money laundering. ${ }^{115}$

\section{(5) Transnational Enforcement of Award}

At the end of arbitration, the arbitral tribunal or institution is expected to make an award, which is synonymous to judgement in case of court litigation. ${ }^{116}$ One of the most striking features of arbitration is the ability to enforce arbitral tribunal's award in a country other than the country of the arbitration situs. ${ }^{117}$ The New York Convention is primary in setting out the recognition and enforcement of awards beyond the country of arbitration situs to a transnational enforceability. Interestingly, the New

\footnotetext{
113 Noussia K., Confidentiality in International Commercial Arbitration: A Comparative Analysis of the Position under English, US, German and French Law, at 17.

114 Andrew de Lotbinière McDougall, "International Arbitration and Money Laundering", American University International Law Review, Vol. 20(5) (October 2005):1.

115 See Dragor Hiber and Vladimir Pavic, "Arbitration and Crime" Journal of International Arbitration, vol. 25Series 4(2008): 463-465.

116 Awards of an arbitration tribunal can be categorized into final awards, partial and interim awards, default awards or consent awards.

117 Gilles Cuniberti, Beyond Contract - The Case for Default Arbitration in International Commercial Disputes, at 424.
} 
York convention has enjoyed wide spread ratification, which further facilitates the easy application of its provisions across virtually more than 149 countries. ${ }^{118}$ The UNCITRAL Model law equally provides for the cross-border enforcement of award, it provides that 'an arbitral award, irrespective of the country in which it was made, shall be recognised as binding and, upon application in writing to the competent court, shall be enforced' in accordance with the related provisions of the Model law. ${ }^{119}$

In addition, the decision or award by the arbitral tribunal or institution is final. Though parties can challenge awards on certain grounds, but it cannot be equated with the process of appeal that is obtainable in court litigation. Some of the grounds for challenging an arbitral award include lack of jurisdiction (it covers issues such as validity, tribunal not properly instituted, and arbitrality), incapacity of either or both parties, lack of due process and contrary to public policy. ${ }^{120}$ Importantly, the transnational enforcement of arbitration awards has remained an outstanding advantage of arbitration over other methods of dispute resolution as well as being in contradistinction with the domestic court's judgement that cannot be enforced across borders. ${ }^{121}$ It is logical that if the award of arbitration cannot be enforced, then it has become a waste of time to arbitrate, and if it is enforceable but is not final, the enforcement of the award may be frustrated. ${ }^{122}$

\footnotetext{
118 See New York Convention Countries at http://www. newyorkconvention.org/new-york-convention-countries (accessed 2 February 2014); Edna Sussman and John Wilkinson, Benefits of Arbitration for Commercial Disputes, at 4. See Article I (1) of the New York Convention on the enforcement of foreign awards. Article 35 (1), UNCITRAL Model law.

See generally the provision of Article 36, UNCITRAL Model law Gilles Cuniberti, Beyond Contract - The Case for Default Arbitration in International Commercial Disputes, at 424.

Babak Hendizadeh, International Commercial Arbitration: The Effect of Culture and Religion on Enforcement of Award, at 13.
} 


\section{CONCLUSION}

Arbitration as a method of dispute resolution has been a significant instrument in resolving international commercial dispute. It has remained the dominant method in the sphere of international commercial dispute resolution, despite the existence of several other methods of dispute resolution including court litigation. The method adopted in arbitration confers the disputants with enormous benefits such as party autonomy, flexible procedure, neutral atmosphere, confidential process, cross-border enforcement of awards, and more. Most of these features are missing in the other methods of dispute resolution that are available to commercial disputants. The nature of an arbitration agreement coupled with the advantages that follow the submission of international commercial disputes to arbitration are factors responsible for the growing trend of arbitration in resolving commercial disputes that have certain foreign elements. It is due to these advantages that arbitration is perceived to be the most preferred devise to resolve international commercial disputes. In view of the advantages to be derived by referring dispute to arbitration, it is suggested that parties to international commercial transactions should imbibe the culture of an inserting arbitration clause or submission agreement in their contracts, in order to make arbitration the mechanism for resolving any dispute that may ensue in the course of their commercial dealings. 